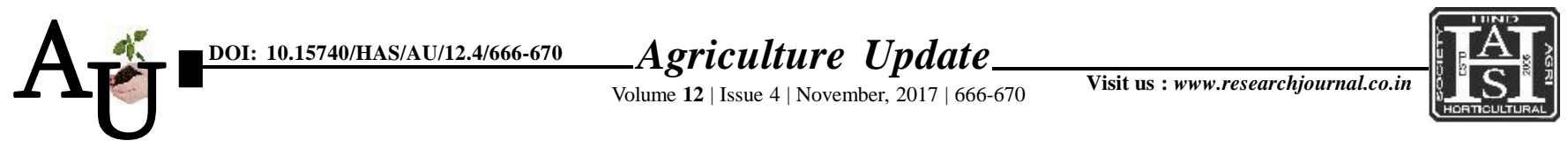

a ISSN-0976-6847

\title{
Research article: Perception as an indicator of soft power: Influence on extension services
}

\author{
ABHISHEK PRATAP SINGH, B. JIRLI, RAHUL KUMAR SINGH AND MANOJ \\ KUMAR
}

Article Chronicle:

Received :

17.08.2017;

Revised :

23.09.2017;

Accepted :

10.10.2017

\section{KEY WORDS:}

Behaviour, Extension service, Perception, Preference, Soft power
SUMMARY : Soft power is a new form of power, described as the ability to influence other behaviour or ability to shape the preferences of others in such a way that it leads to the achievement of the targeted purpose. In other words, soft power could be seen as the ability to use the power of attraction ability to direct the preference of others a kind of identification and attraction based referent power denoted by perceptions. Therefore, in the present study farmer perception has been selected an indicator soft power and its relationship with agricultural extension services. Present study was conducted on the 220 respondents in two districts of Eastern Uttar Pradesh i.e., Varanasi and Mirzapur. Data were obtained on the basis of interview schedule. The findings of chi-square test indicated that there were no significant differences between most of the extension services provided by public or private sectors which mean famer perception towards public and private extension service were found to be different. Finally, the results indicated that in particular services private sector was found to be better than public sector services. Limitations and future research suggestions were also discussed.

How to cite this article : Singh, Abhishek Pratap, Jirli, B., Singh, Rahul Kumar and Kumar, Manoj (2017). Perception as an indicator of soft power: Influence on extension services. Agric. Update, 12(4): 666-670; DOI : 10.15740/HAS/AU/12.4/666-670.
Author for correspondence : ABHISHEK PRATAP SINGH

Janta College Bakewar, ETAWAH (U.P.) INDIA

Email:apsbhu7@ gmail.com

See end of the article for authors' affiliations 